\title{
Analisis Persepsi Masyarakat Lokal Terhadap TPA Baru Wilayah Barat Bojonegoro dengan Metode SEM
}

\author{
Rizal Zubad Firdausi ${ }^{1}$, Agus Budianto ${ }^{2}$ \\ ${ }^{1,2}$ Magister Teknik Lingkungan, Fakultas Teknik Sipil dan Perencanaan, Institut Teknologi Adhi Tama Surabaya \\ Email: ${ }^{1}$ rizalzubadfirdausi@gmail.com
}

\begin{abstract}
Knowledge of public perceptions of the TPA in new areas is needed in policy planning to implement and operate the New TPA in Bojonegoro, especially the perceptions of the community around the TPA. This study explains the perceptions of the community around the TPA using the Structural Equation Modeling method with the assumption of a casual relationship between the latent variables of social status, perceptions of information, beliefs, perceptions of benefits, and perceptions of risk on local people's acceptance of the New TPA. Results of the whole model test is the chi-square value of 364,508, there are 4 criteria that are declared good fit, 7 criteria are declared marginal fit and 3 criteria are declared poor fit. This means that this model can be categorized as moderate (close to good), so this model is quite feasible to be used as an analysis model. While the results of the model fit test show the relationship of the model structure, it is found that the relationship between social status is only significant to the perceived benefit variable, which is indicated by the results of $t$-value (3.003)> 1.96 and $p$-value $(0.027)<0.05$. This means that the social status of the community has a significant effect on the perception of the benefits of the TPA, while the perception of acceptance of the New TPA is significantly influenced by the perception of information and the perception of the benefits of the community around the TPA, this confirms that the perception of community acceptance of the new TPA is strongly influenced by the factors of receiving information and perceptions perceived benefits
\end{abstract}

Keywords: Bojonegoro, Community Perception, Structural Equation Modeling, New TPA

\begin{abstract}
Abstrak
Pengetahuan persepsi publik terhadap TPA di wilayah baru dibutuhkan dalam perencanaan kebijakan untuk menerapkan dan mengoperasikan TPA Baru di Bojonegoro, terutama persepsi dari masyarakat disekitar TPA. Studi ini menjelaskan persepsi masyarakat sekitar TPA dengan metode Structural Equation Modeling dengan asumsi hubungan kasual antara variabel laten status sosial, persepsi informasi, kepercayaan, persepsi manfaat, dan persepsi resiko pada penerimaan masyarakat lokal terhadap TPA Baru. Dari hasil uji keseluruhan model dengan nilai chi-square sebesar 364,508, terdapat 4 kriteria dinyatakan baik (good fit), 7 kriteria dinyatakan sedang (marginal fit) dan 3 kriteria dinyatakan buruk (poor fit). Artinya model ini bisa dikategorikan sedang (mendekati baik), sehingga cukup layak untuk dijadikan model analisis. Sedangkan hasil dari uji kecocokan model menununjukkan hubungan dari struktur model diperoleh bahwa hubungan status sosial hanya bernilai signifikan terhadap variabel persepsi manfaat, yang ditunjukkan dengan hasil t-value $(3,003) \geq 1,96$ dan $p$-value $(0,027) \leq 0,05$. Artinya bahwa status sosial masyarakat berpengaruh signifikan terhadap persepsi mengenai manfaat TPA, sedangkan persepsi penerimaan terhadap TPA Baru secara signifikan dipengaruhi dari persepsi informasi dan persepsi manfaat masyarakat sekitar TPA, hal ini mengkonfirmasi bahwa persepsi penerimaan masyarakat terhadap TPA baru sangat dipengaruhi oleh faktor penerimaan informasi dan persepsi manfaat yang dirasakan.
\end{abstract}

Kata kunci: Bojonegoro, Persepsi Masyarakat, Structural Equation Modeling, TPA Baru

\section{Pendahuluan}

Persoalan sampah adalah persoalan yang pasti dihadapi oleh semua manusia baik sebagai individu, keluarga maupun masyarakat. Persoalan sampah juga menjadi permasalahan yang dihadapi suatu wilayah, mulai dari skala kecil seperti pada tingkat dusun, desa, kecamatan, kabupaten/kota 
bahkan pada sebuah negara. Saat ini, lebih dari 50 persen populasi dunia tinggal di kota-kota, dan tingkat urbanisasi meningkat dengan cepat. Ini akan menambah tantangan pengelolaan sampah [1][2], dan 80\% masyarakat tidak bersedia ada TPA disekitar tempat tinggal mereka [3]. Upaya mengurangi sampah yang sampai di TPA dapat dilaukan dengan memanfaatkan sampah menjadi produk yang bermanfaat [4],[5][6][7].

Berdasarkan data yang diperoleh dari Dinas Lingkungan Hidup Kabupaten Bojonegoro, timbulan sampah yang terangkut dan terlayani oleh TPA Lama Bojonegoro pada tahun 2018 sebanyak $263,81 \mathrm{~m}^{3} /$ hari atau sebesar 92,34 ton/hari, dimana wilayah pelayanan persampahan pada TPA Kabupaten Bojonegoro yang hanya melayani 9 Kecamatan di Bojonegoro dan pada tahun 2019 TPA Lama dinyatakan overload dan di bangun TPA Baru Wilayah Barat Bojonegoro pada tahun 2019 [8]. Seperti kita ketahui, bahwa TPA secara umum dapat mencemari tanah, air [9], [10], dan udara serta berkontribusi terhadap lalu lintas kendaraan dan kebisingan, mempromosikan fauna berbahaya dan mengganggu pemandangan estetika [11].

Sebagai salah satu dasar perencanaan kegiatan pengoperasian perlu memperhatikan persepsi masyarakat lokal sekitar TPA baru, menjadi penting melakukan kajian persepsi masyarakat lokal untuk menentukan strategi dalam merumuskan kebijakan dan mengurangi dampak sosial terhadap TPA baru tersebut [12]. Adapun yang dimaksud persepsi adalah suatu proses yang ditempuh individu-individu untuk mengorganisasikan dan menafsirkan kesan indera mereka agar memberi makna. [13].

Dalam hal ini, masyarakat dapat menerima dengan segala konsekuensinya, menerima dengan konsekuensi tertentu atau bahkan menolak sama sekali keberadaan TPA di lingkungan mereka. Tanggapan masyarakat ini terkait erat dengan tingkat pengetahuan dan persepsi masyarakat itu sendiri, untuk mengetahui tanggapan masyarakat terkait keberadaan TPA Bojonegoro

\section{Metode}

\section{Waktu dan Lokasi}

Penelitian ini dimulai dengan desain kuisioner skala likert untuk menyanyakan kepada penduduk sekitar TPA baru mengenai persepsi mereka terhadap TPA baru wilayah barat Bojonegoro yang bertempat di desa Bandungrejo Kecamatan Ngasem, Kabupaten Bojonegoro, Provinsi Jawa Timur. Penelitian dilakukan selama 3 bulan dari Bulan Februari-Mei 2020.

\section{Prosedur}

Pengumpulan data dilakukan dengan teknik wawancara kepada penduduk sekitar TPA Baru Wilayah Barat Bojonegoro dengan populasi jumlah penduduk Desa Bandungrejo Kecamatan Ngasem Kabupaten Bojonegoro yaitu sebesar 3.285 jiwa [14]

Sampling dilakukan untuk menggali data persepsi masyarakat mengenai TPA Baru. Untuk menentukan besaran sampel dalam penelitian ini menggunakan tabel yang telah diformulakan oleh Krejcie dan Morgan dengan formula penentuan ukuran sampel dengan asumsi tingkat kepercayaan 95\% dengan polulasi sebesar 3.285 digolongkan dengan $\mathrm{N}=3.500$ sehingga didapat sample sebesar 346 sampel [15], adapun kriteria responden adalah masyarakat sekitar TPA berusia 18-60 tahun Pendidikan minimal SD, Penduduk asli atau telah berdomisili minimal 6 tahun. Selanjutnya untuk menentukan siapa saja yang akan menjadi sampel dalam penelitian ini digunakan teknik sistematik sampling, yaitu penarikan sampel dengan memilih elemen pada urutan tertentu.

\section{Desain Kuisioner}

Dalam penelitian ini, aspek sosial dinilai dari persepsi publik terhadap akan adanya keberadaan TPA baru. Karena dalam penelitian ini adalah mencari persepsi masyarakat dari TPA yang belum ada sebelumnya, maka variabel yang digunakan akan mencakup pertanyaan tentang persepsi sosial dengan 6 (enam) variabel laten yaitu: status sosial, persepsi informasi, kepercayaan, persepsi resiko, persepsi manfaat, dan persepsi penerimaan [16]. Dalam kuesioner penelitian ini menggunakan 5-point skala 
Likert. Dalam bukunya, Joshi menjelaskan bahwa konstruksi skala Likert bertujuan untuk memahami tentang persepsi / pendapat peserta terkait dengan yang diasumsikan variabel laten [17]

Tabel 1. Tabel Kuisioner Persepsi Masyarakat Terhadap TPA Baru Bojonegoro (Skala likert 1-5)

\begin{tabular}{|c|c|c|}
\hline Var & Kode & Pertanyaan \\
\hline \multirow{3}{*}{ 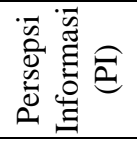 } & PI1 & TPA Baru ini tidak mempengaruhi lingkungan \\
\hline & PI2 & Informasi terperinci tentang dampak negatif TPA terdahulu yang seharusnya tersedia \\
\hline & PI3 & Kegiatan yang dilakukan di TPA bisa diakses \\
\hline \multirow{8}{*}{ 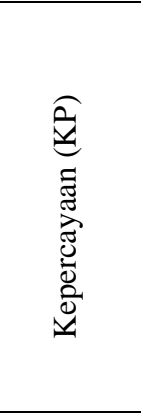 } & KP1 & Informasi lengkap mengenai pengolahan sampah di TPA dapat dijangkau \\
\hline & KP2 & TPA baru akan lebih efisien \\
\hline & KP3 & TPA baru akan aman \\
\hline & KP4 & Kebijakan pengelolaan sampah oleh pemerintah dapat dipercaya \\
\hline & KP5 & $\begin{array}{l}\text { Pemerintah secara terbuka telah secara terbuka memberikan informasi kepada publik } \\
\text { mengenai TPA }\end{array}$ \\
\hline & KP6 & Pemerintah memiliki kemampuan untuk menangani dampak negatif yang akan terjadi. \\
\hline & KP7 & Staf yang mengelola TPA kompeten \\
\hline & KP8 & Pengelola TPA telah dikenal masyarakat \\
\hline \multirow{5}{*}{ 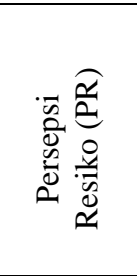 } & PR1 & Tingkat resiko dampak negatif di TPA lebih besar dari resiko di jalan raya \\
\hline & PR2 & Kerusakan lingkungan, dan bahaya kesehatan akan terjadi saat pengoprasian TPA \\
\hline & PR3 & Merasa khawatir jika didekat TPA \\
\hline & PR4 & $\begin{array}{l}\text { Kecelakaan pada pengoprasian TPA dapat mengakibatkan kerusakan lingkungan dan } \\
\text { bahaya kesehatan }\end{array}$ \\
\hline & PR5 & Bertempat tinggal di dekat TPA itu berbahaya \\
\hline \multirow{5}{*}{ 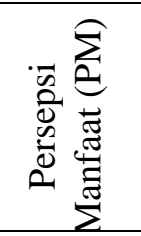 } & PM1 & TPA dapat membuka lapangan kerja baru \\
\hline & PM2 & Kegiatan ekonomi akan tumbuh di sekitar TPA \\
\hline & PM3 & TPA dapat mengolah sampah organik menjadi pupuk \\
\hline & PM4 & Sampah anorganik di TPA dapat menjadi pendapatan bagi pemulung \\
\hline & PM5 & Adanya TPA akan menjadikan lingkungan lebih bersih \\
\hline \multirow{4}{*}{ 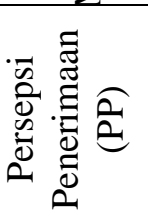 } & PP1 & Harus ada TPA di wilayah barat Bojonegoro \\
\hline & PP2 & TPA harus berada di wilayah yang jauh dari pemukiman \\
\hline & PP3 & Menerima pembangunan konstruksi di dekat TPA \\
\hline & PP4 & Konstruksi TPA sangat bermanfaat \\
\hline
\end{tabular}

\section{Hasil dan Pembahasan}

Selain pertanyaan skala Likert, pertanyaan lain seperti status sosial dan lokasi rumah, juga dimasukkan dalam kuisioner. Pertanyaan pada status sosial ini diwakili dengan kode SS1 - SS7 yaitu jenis kelamin, usia, pendidikan, pekerjaan, pendapatan bulanan rumah tangga, Jarak rumah dengan TPA Baru Bojonegoro, apakah bekerja atau memiliki teman yang bekerja di TPA. Analisis Structural Equation Modeling (SEM) dipilih karena SEM merupakan bagian dari analisis multivariate dengan metode pengolahan peubah (respon) yang jumlahnya lebih dari satu, dan tujuannya untuk mencari

pengaruh peubah-peubah terhadap suatu obyek secara serentak [18]. Analisis multivariat mengacu pada semua metode statistika yang menganalisis beberapa pengukuran pada setiap objek yang diamati secara simultan [19], dimana analisis SEM merupakan gabungan dari analisis faktor dan analisis regresi yang memungkinkan peneliti untuk menguji rangkaian hubungan yang saling terkait antara variabel terukur dengan variabel laten [20]. 
Selain melakukan uji validitas dan reliabilitas instrumen juga dilakukan uji kecocokoan model struktural untuk mengetahui good of fitness dari model yang ada [21] dimana dalam melakukan analisis menggunakan aplikasi SPSS 25 [12] dan AMOS 22

Dalam pengukuran daya dukung TPA Baru Wilayah Barat Bojonegoro dari aspek sosial, dilakukan dengan kuisioner terhadap 346 orang di sekitar TPA

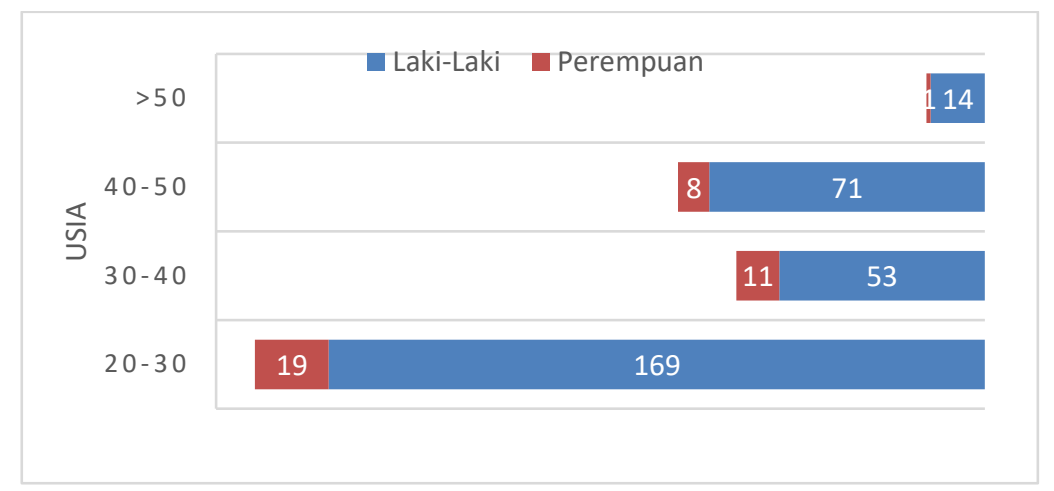

Gambar 1. Jumlah responden berdasar usia dan jenis kelamin

Demografi responden seperti pada gambar 1, rata-rata berusia 20-30 tahun (54\% dari responden), sedangkan jenis klamin responden laki-laki sebesar $89 \%$ sedang responden dengan jenis kelamin perempuan sebesar $11 \%$. Mayoritas tingkat pendidikan responden berdasar gambar 2 adalah tamatan SMA Sederajat (sebesar 214 responden atau 62\% dari total responden), sedangkan dari pekerjaan responden mayoritas sebanyak 209 (60\%) orang bekerja sebagai petani dan beberapa responden berpendidikan S1 dan S2 dengan pekerjaan Guru (3\%) dan PNS (3\%) seperti pada Gambar 3 dan 4.

Sedangkan dari sisi jarak menurut Gambar 5, responden yang diambil datanya $80 \%$ responden bertempat tinggal dengan jarak kurang dari $1 \mathrm{~km}$ dan yang paling dekat adalah $500 \mathrm{~m}$. Di area jarak kurang dari $500 \mathrm{~m}$ dari TPA baru tidak pemukiman/rumah penduduk. Sedangkan dari sisi penghasilan, rata-rata responden berpenghasilan 1-2 juta rupiah per bulan.

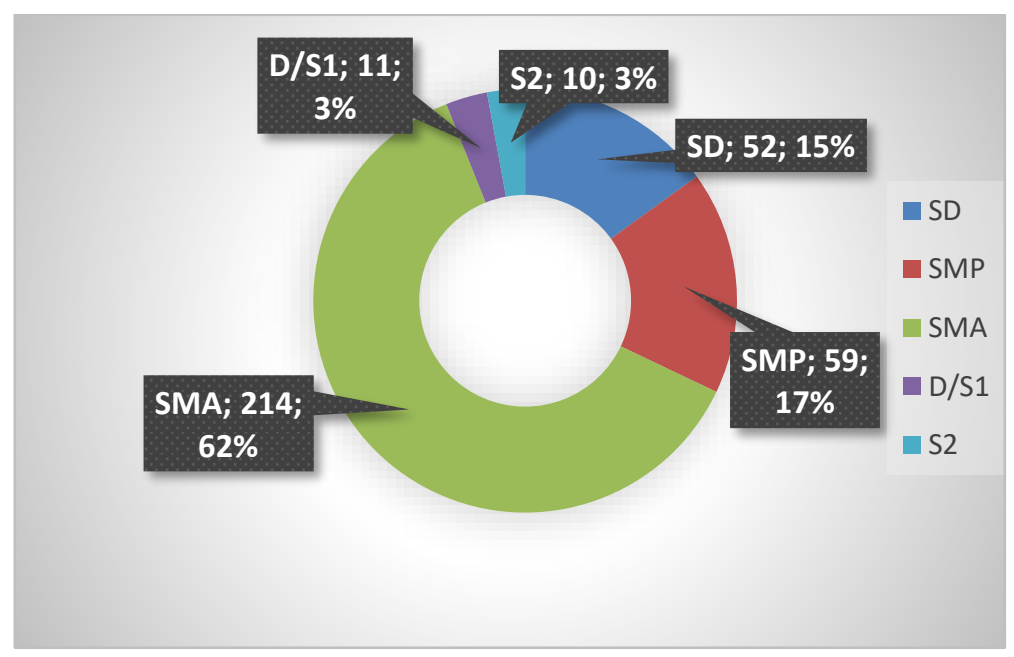

Gambar 2. Pendidikan Responden 


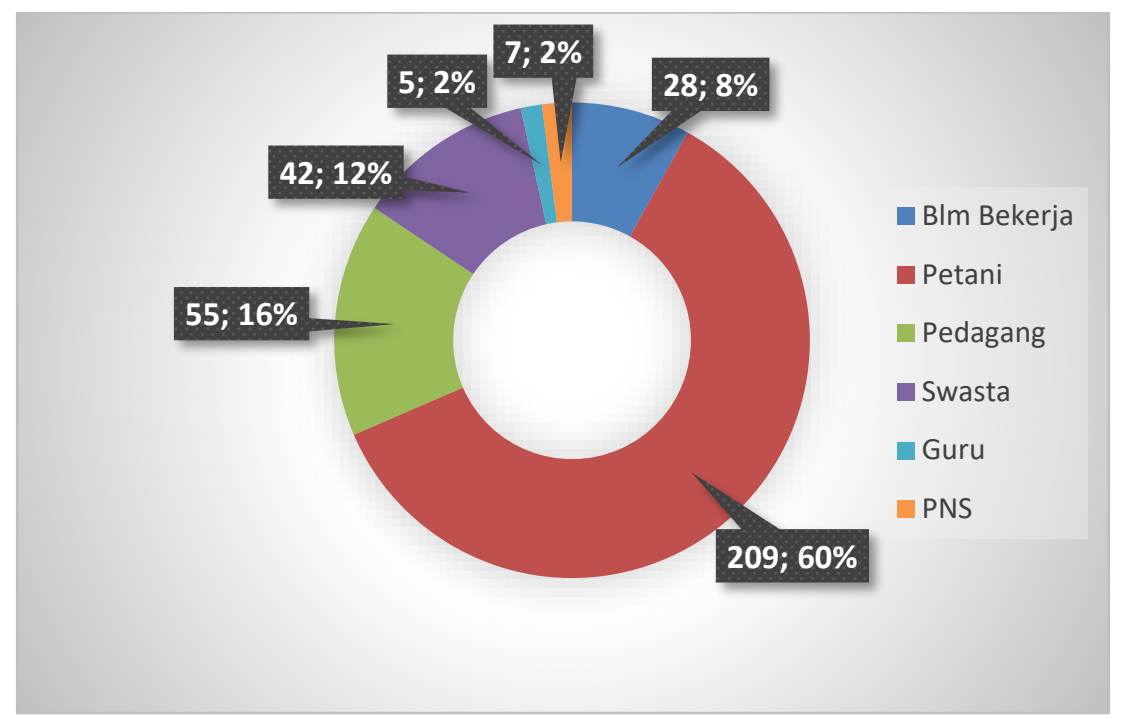

Gambar 3. Pekerjaan Responden

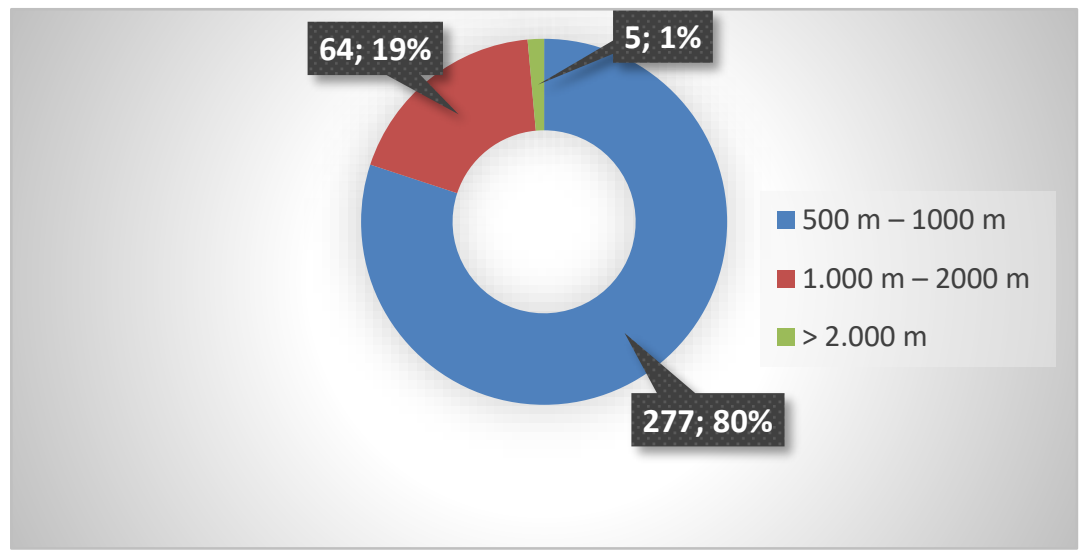

Gambar 4. Penghasilan Responden per Bulan

\section{Uji Validitas dan Reliabilitas}

Untuk mendapatkan kesimpulan yang valid, perlu dilakukan uji validitas dan reliabilitas terhadap kuisioner sebagai alat ukur persepsi masyarakat, berdasarkan tabel 2, diperoleh kesimpulan bahwa setiap item pertanyaan masing-masing variabel peneilitan dinyatakan valid, dengan jumlah sampel $n=30$ dan taraf signifikan 5\%. Hal ini berdasarkan hasil dari nilai $r_{\text {hitung }}$ dari setiap item lebih besar dari $r_{\text {tabel }}(\alpha: n-$ $2)=0,261$. Pengujian reliabel dari masing-masing item pertanyaan memberikan nilai Alpha Cronbach lebih besar dari 0.60 , sehingga dapat dikatakan kuesioner tersebut reliabel. Hasil dikuatkan dengan nilai Alpha Croncbach untuk seluruh item pertanyaan sebesar 0,965.

\section{Struktur Jalur Variabel}

Kami menentukan jalur berdasarkan penelitian [16]. Dari literatur, ditemukan bahwa status sosial tampaknya secara langsung mempengaruhi persepsi risiko [22], [23], persepsi manfaat, dan penerimaan teknologi. 
Tabel 2. Hasil perhitungan validitas dan reliabilitas

\begin{tabular}{ccccc}
\hline Kode & $\begin{array}{c}\text { Nilai } \\
\mathrm{r}_{\text {hitung }}\end{array}$ & $\begin{array}{c}\text { Validitas } \\
\mathrm{R}_{\text {hitung } \geq \mathrm{r}_{\text {table }}}(0,261)\end{array}$ & $\begin{array}{c}\text { Nilai Alpha } \\
\text { Cronbach }\end{array}$ & $\begin{array}{c}\text { Reliabilitas } \\
\alpha \geq 0,60\end{array}$ \\
\hline PI1 & 0,899 & Valid & 0,962 & Reliabel \\
\hline PI2 & 0,846 & Valid & 0,963 & Reliabel \\
\hline PI3 & 0,790 & Valid & 0,963 & Reliabel \\
\hline KP1 & 0,910 & Valid & 0,962 & Reliabel \\
\hline KP2 & 0,767 & Valid & 0,963 & Reliabel \\
\hline KP3 & 0,852 & Valid & 0,963 & Reliabel \\
\hline KP4 & 0,852 & Valid & 0,963 & Reliabel \\
\hline KP5 & 0,855 & Valid & 0,963 & Reliabel \\
\hline KP6 & 0,702 & Valid & 0,964 & Reliabel \\
\hline KP7 & 0,560 & Valid & 0,966 & Reliabel \\
\hline KP8 & 0,639 & Valid & 0,965 & Reliabel \\
\hline PR1 & 0,676 & Valid & 0,964 & Reliabel \\
\hline PR2 & 0,621 & Valid & 0,965 & Reliabel \\
\hline PR3 & 0,474 & Valid & 0,967 & Reliabel \\
\hline PR4 & 0,818 & Valid & 0,963 & Reliabel \\
\hline PR5 & 0,819 & Valid & 0,963 & Reliabel \\
\hline PM1 & 0,789 & Valid & 0,963 & Reliabel \\
\hline PM2 & 0,813 & Valid & 0,963 & Reliabel \\
\hline PM3 & 0,777 & Valid & 0,963 & Reliabel \\
\hline PM4 & 0,731 & Valid & 0,964 & Reliabel \\
\hline PM5 & 0,814 & Valid & 0,963 & Reliabel \\
\hline PP1 & 0,708 & Valid & 0,964 & Reliabel \\
\hline PP2 & 0,841 & Valid & 0,963 & Reliabel \\
\hline PP3 & 0,693 & Valid & 0,964 & Reliabel \\
\hline PP4 & 0,501 & Valid & 0,966 & Reliabel \\
\hline & & & & \\
\hline
\end{tabular}

Persepsi informasi tampaknya secara langsung mempengaruhi persepsi risiko, persepsi manfaat, dan penerimaan teknologi. Studi juga menunjukkan bahwa status sosial dan persepsi informasi mempengaruhi kepercayaan. Kepercayaan tampaknya secara langsung mempengaruhi persepsi risiko [24], persepsi manfaat, dan penerimaan teknologi, dan juga menimbulkan dampak tidak langsung pada penerimaan teknologi (melalui risiko, persepsi manfaat). Selain itu, persepsi risiko tampaknya secara langsung mempengaruhi penerimaan teknologi dan persepsi manfaat tampaknya secara langsung mempengaruhi penerimaan teknologi. Karenanya, kepercayaan, persepsi risiko, dan persepsi manfaat diperlakukan sebagai variabel intervening dalam model kami. Adapun struktur jalur variabel ditunjukkan dalam Gambar 6.

Setelah dilakukan analisis diagram dengan menggunakan aplikasi AMOS 22, maka seperti pada Gambar 7 diperoleh hasil bahwa chi square sebesar 2.182,83 dimana seharusnya semakin kecil nilai chi square maka semakin baik model tersebut, dari teks output hasil analisis tersebut, sudah memenuhi ketentuan standar minimal yaitu tidak ada unique variable yang minus, oleh sebab itu dilakukan modifikasi dengan menghapus beberapa indikator yang bernilai negatif atau yang kurang dari 0,5 


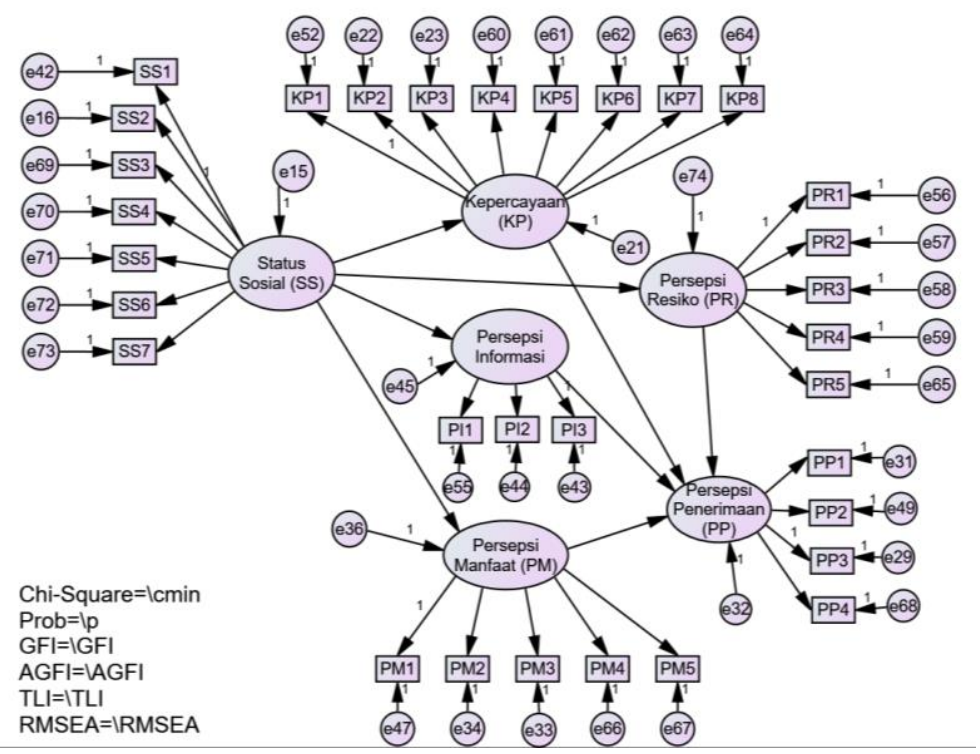

Gambar 6. Struktur jalur variabel persepsi masyarakat terhadap TPA baru

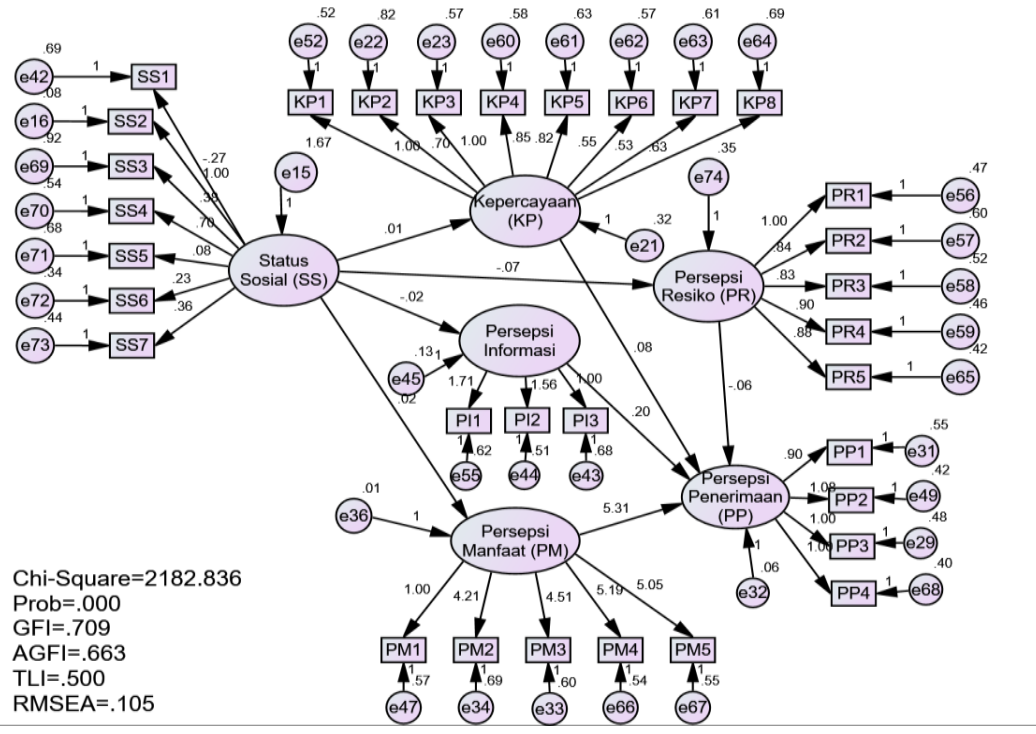

Gambar 7. Hasil analisis diagram dengan aplikasi AMOS 22 


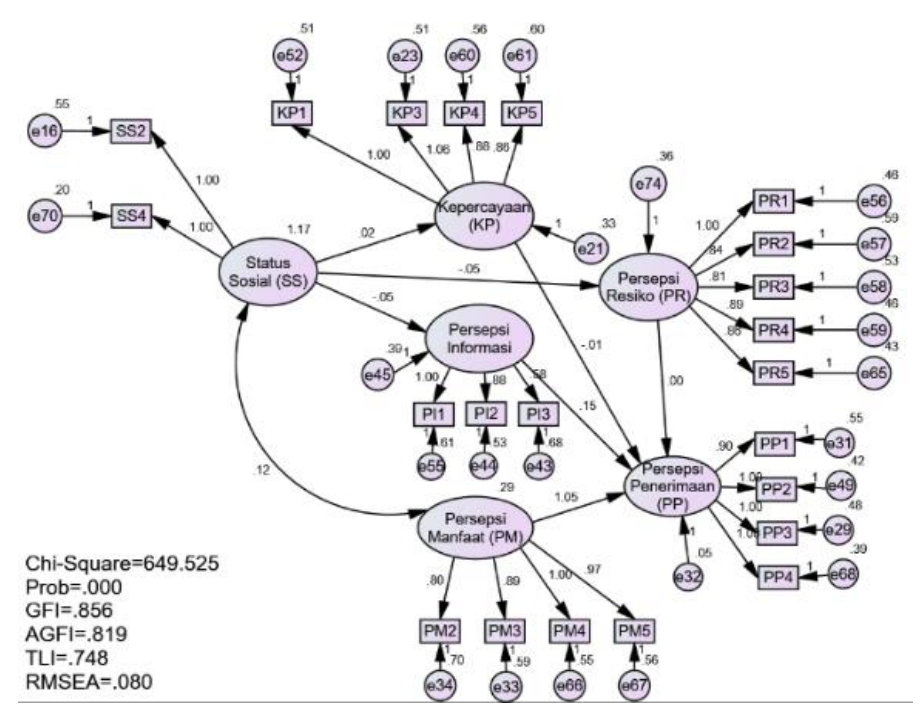

Gambar 8. Diagram path hasil analisis setelah dilakukan modifikasi melalui Amos 22

\section{Uji Kecocokan Keseluruhan Model}

Pada penelitian ini, peneliti menggunakan Structural Equation Modelling (SEM) di mana metode ini menguji secara bersama-sama model yang terdiri dari variabel independen dan variabel dependen.

Setelah lolos pengujian validitas dan reliabilitas, dan modifikasi model untuk mendapatkan model yang baik, maka tahap selanjutnya adalah menganalisis kecocokan data dengan model secara keseluruhan atau dalam AMOS disebut Goodness of Fit (GoF) [21]. Pengujian ini akan mengevaluasi apakah model yang dihasilkan merupakan model fit atau tidak. Analisis kecocokan keseluruhan model dapat dilihat dari angka statistik pada tabel 3.

Dari hasil uji kecocokan, dinyatakan bahwa dari 14 kriteria goodness of fit 4 kriteria dinyatakan baik (good fit), 7 kriteria dinyatakan sedang (marginal fit) dan 3 kriteria dinyatakan buruk (poor fit). Dari rata-rata hasil uji kecocokan model, maka model ini bisa dikategorikan sedang mendekati baik, sehingga model ini cukup layak untuk dijadikan model analisis.

Gambar 8 menunjukkan model SEM setelah modifikasi, terlihat bahwa nilai chi-square setelah modifikasi sebesar 364.508 sedangkan nilai chi-square sebelum modifikasi sebesar 1448.702 ini artinya nilai chi-square setelah modifikasi lebih kecil atau berkurang dari sebelumnya, walaupun belum bisa dikatakan Good Fit namun model ini telah memenuhi standar minimum dari aplikasi Amos 22.

\section{Uji Kecocokan Model Struktural}

Berdasarkan hasil uji hubungan antar faktor yang telah dilakukan sebelumnya, 3 dari 8 hubungan antar faktor membuktikan adanya hubungan signifikan pada tingkat keyakinan 95\% dengan t-value > 1,96. Pada tabel 3 menunjukkan kesimpulan hasil uji kecocokan model yang dianalisis

Tabel 3. Uji Kecocokan Keseluruhan Model (Goodness of Fit)

\begin{tabular}{llll}
\hline \multicolumn{1}{c}{ Ukuran GOF } & \multicolumn{1}{c}{ Target Tingkat Kecocokan } & \multicolumn{1}{c}{ Hasil Estimasi $^{\mathbf{b}}$} & Tingkat Kecocokan $^{-}$ \\
\hline Chi-Square $\left(\mathrm{x}^{2}\right)$ & Nilai $\mathrm{x}^{2}$ yang kecil & $\mathrm{x}^{2}=649,52$ & Tidak baik (poor fit) \\
$\mathrm{p}$-value & $\mathrm{p} \geq 0,05$ & $(\mathrm{p}=0.000)$ & \\
Noncentrality & Nilai yang kecil & 447,525 & Tidak baik (poor fit) \\
Parameter (NCP) & Interval yang sempit & $(374.245-528,413)$ & \\
\hline
\end{tabular}




\begin{tabular}{|c|c|c|c|}
\hline Ukuran GOF & Target Tingkat Kecocokan ${ }^{a}$ & Hasil Estimasi $^{\mathbf{b}}$ & Tingkat Kecocokan \\
\hline $\begin{array}{l}\text { Root Mean Square } \\
\text { Residual (RMR) }\end{array}$ & $\mathrm{RMR} \leq 0.05$ & 0,113 & $\begin{array}{l}\text { Sedang (Marginal } \\
\text { fit) }\end{array}$ \\
\hline $\begin{array}{l}\text { Root Mean Square } \\
\text { Error of Approxi- } \\
\text { mation (RMSEA) }\end{array}$ & $\begin{array}{l}\text { RMSEA } \leq 0.08 \text { adalah } \text { good fit, sedangkan } \\
\text { RMSEA } \leq 0.05 \text { adalah close fit }\end{array}$ & 0,080 & Baik (good fit) \\
\hline $\begin{array}{l}\text { Expected Cross- } \\
\text { Validation Index } \\
\text { (ECVI) }\end{array}$ & $\begin{array}{l}\text { Nilai ECVI yang lebih dekat pada saturated } \\
\text { ECVI dibanding pada ECVI for independence } \\
\text { model, termasuk good fit. }\end{array}$ & $\begin{array}{l}M^{*}=2,178 \\
S^{*}=1,467 \\
I^{*}=6,692\end{array}$ & Baik (good fit) \\
\hline $\begin{array}{l}\text { Goodness of Fit } \\
\text { Index (GFI) }\end{array}$ & $\begin{array}{l}\text { Nilai semakin mendekati } 1 \\
\text { semakin baik. GFI } \geq 0.9 \text { adalah good fit, } \\
\text { sedangkan } 0.08 \leq \mathrm{GFI} \leq 0.90 \text { termasuk maginal fit. }\end{array}$ & 0,856 & $\begin{array}{l}\text { Sedang (Marginal } \\
\text { fit) }\end{array}$ \\
\hline $\begin{array}{l}\text { Akaike Information } \\
\text { Criterion (AIC) }\end{array}$ & $\begin{array}{l}\text { Nilai AIC dari model yang mendekati nilai } \\
\text { saturated AIC dibanding pada independence AIC } \\
\text { menunjukkan good fit. }\end{array}$ & $\begin{array}{l}M^{*}=751,525 \\
S^{*}=506,00 \\
I^{*}=2308,73\end{array}$ & Baik (good fit) \\
\hline $\begin{array}{l}\text { Consistent Akaike } \\
\text { Information } \\
\text { Criterion (CAIC) }\end{array}$ & $\begin{array}{l}\text { Nilai CAIC model yang lebih dekat pada nilai } \\
\text { saturated CAIC disbanding pada independence } \\
\text { AIC menunjukkan good fit. }\end{array}$ & $\begin{array}{l}\mathrm{M}^{*}=998,694 \\
\mathrm{~S}^{*}=1732.149 \\
\mathrm{I}^{*}=2415.348 \\
\end{array}$ & Baik (good fit) \\
\hline $\begin{array}{l}\text { Normed Fit Index } \\
\text { (NFI) }\end{array}$ & $\begin{array}{l}\mathrm{NFI} \geq 0.9 \text { adalah } \text { good fit, sedangkan } \\
0.08<\mathrm{NFI}<0.90 \text { termasuk maginal fit. }\end{array}$ & 0,713 & Sedang (Marginal fit) \\
\hline $\begin{array}{l}\text { Comparative Fit } \\
\text { Index (CFI) }\end{array}$ & $\begin{array}{l}\text { CFI } \geq 0.9 \text { adalah } \text { good fit, sedangkan } \\
0.08 \leq \mathrm{CFI} \leq 0.90 \text { termasuk maginal fit. }\end{array}$ & 0,682 & $\begin{array}{l}\text { Sedang (Marginal } \\
\text { fit) }\end{array}$ \\
\hline $\begin{array}{l}\text { Incremental Fit } \\
\text { Index (IFI) }\end{array}$ & $\begin{array}{l}\text { IFI } \geq 0.9 \text { adalah } \text { good fit, sedangkan } \\
0.08 \leq \mathrm{IFI} \leq 0.90 \text { termasuk maginal fit. }\end{array}$ & 0,783 & $\begin{array}{l}\text { Sedang (Marginal } \\
\text { fit) }\end{array}$ \\
\hline $\begin{array}{l}\text { Relative Fit Index } \\
\text { (RFI) }\end{array}$ & $\begin{array}{l}\text { RFI } \geq 0.9 \text { adalah good fit, sedangkan } \\
0.08 \leq \mathrm{RFI} \leq 0.90 \text { termasuk maginal fit. }\end{array}$ & 0,672 & $\begin{array}{l}\text { Sedang (Marginal } \\
\text { fit) }\end{array}$ \\
\hline $\begin{array}{l}\text { Adjustet Goodness } \\
\text { of Fit Index (AGFI) }\end{array}$ & $\begin{array}{l}\text { AGFI } \geq 0.9 \text { adalah } \text { good fit, sedangkan } \\
0.08 \leq \mathrm{A} G F I \leq 0.90 \text { termasuk maginal fit. }\end{array}$ & 0,819 & $\begin{array}{l}\text { Sedang (Marginal } \\
\text { fit) }\end{array}$ \\
\hline Critical N (CN) & $\mathrm{CN} \geq 200$ & 134 & Tidak baik (poor fit) \\
\hline
\end{tabular}

Sumber: output Amos olahan peneliti

\begin{tabular}{|c|c|c|}
\hline Hubungan & t-value & Estimasi \\
\hline $\mathrm{KP} \leftarrow \mathrm{SS}$ & 0,474 & 0,018 Tidak Signifikan \\
\hline $\mathrm{PR} \leftarrow \mathrm{SS}$ & $-1,295$ & $-0,049$ Tidak Signifikan \\
\hline $\mathrm{PI} \leftarrow \mathrm{SS}$ & $-1,090$ & $-0,049$ Tidak Signifikan \\
\hline $\mathrm{PM} \leftarrow \mathrm{SS}$ & 3,003 & 0,101 Signifikan \\
\hline $\mathrm{PP} \leftarrow \mathrm{KP}$ & $-0,086$ & $\begin{array}{ll}-0,007 & \text { Tidak Signifikan }\end{array}$ \\
\hline $\begin{array}{l}\text { Hubungan } \\
\text { Hob }\end{array}$ & t-value & Estimasi \\
\hline $\mathrm{PP} \leftarrow \mathrm{PM}$ & 6,997 & 1,048 Signifikan \\
\hline PP $\leftarrow$ PI & 1,995 & $0,155^{\text {Signifikan }}$ \\
\hline$\overline{P P} \leftarrow \mathrm{PR}$ & $-0,061$ & $-0,004^{\text {Tidak Signifikan }}$ \\
\hline
\end{tabular}

Tabel 4: Signifikansi dari Hasil Korelasi 


\begin{tabular}{|c|c|c|c|}
\hline \multirow{2}{*}{ Hubungan } & Langsung & $\begin{array}{c}\text { Tidak } \\
\text { Langsung }\end{array}$ & \multirow[t]{2}{*}{ Hasil } \\
\hline & $(\boldsymbol{\beta})$ & $(\beta) \quad(p)$ & \\
\hline $\mathrm{KP} \leftarrow \mathrm{SS}$ & $0,0330,758$ & & Tidak Signifikan \\
\hline $\mathrm{PR} \leftarrow \mathrm{SS}$ & $-0,0870,168$ & & Tidak Signifikan \\
\hline $\mathrm{PI} \leftarrow \mathrm{SS}$ & $-0,0840,312$ & & Tidak Signifikan \\
\hline $\mathrm{PM} \leftarrow \mathrm{SS}$ & $0,2030,027^{*}$ & & Signifikan \\
\hline $\mathrm{PP} \leftarrow \mathrm{KP}$ & $-0,0060,955$ & & Tidak Signifikan \\
\hline $\mathrm{PP} \leftarrow \mathrm{PM}$ & $0,9230,001 * *$ & & Signifikan \\
\hline$\overline{\mathrm{PR} \leftarrow \mathrm{PI}}$ & $0,1590,050^{*}$ & & Signifikan \\
\hline $\mathrm{PP} \leftarrow \mathrm{PR}$ & $-0,0040,940$ & & Tidak Signifikan \\
\hline$P P \leftarrow S S$ & & $\begin{array}{c}0,0980.03 \\
3 *\end{array}$ & \\
\hline
\end{tabular}

$$
* \boldsymbol{p} \leq 0.05 ; \quad * * \boldsymbol{p} \leq 0.01
$$

Hubungan variabel independen terhadap variabel dependen terkait sebagai hasil pengukuran structural second order CFA (2ndCFA) ditunjukkan pada tabel 4, dan dari hasil uji kecocokan model struktural dengan melakukan uji hubungan antar variabel maka diperoleh bahwa hubungan status sosial (SS) hanya bernilai signifikan terhadap variabel Persepsi Manfaat (PM), yang ditunjukkan dengan hasil $\mathrm{t}$-value $(3,003) \geq 1,96$ dan $p$-value $(0,027) \leq 0,05$. Hal ini ini menunjukan bahwa semakin tinggi status sosial masyarakat akan meningkatkan persepsi manfaat terhadap TPA. Sedangkan persepsi penerimaan terhadap TPA secara signifikan dipengaruhi dari persepsi informasi (PI) dan persepsi manfaat (PM), hasil ini mengkonfirmasi bahwa untuk persepsi masyarakat pada sesuatu yang baru dalam hal ini TPA baru wilayah barat Bojonegoro, yang mampu merefleksikan penerimaan masyarakat adalah faktor informasi dan manfaat yang diketahui dan dirasakan masyarakat. Untuk faktor Kepercayaan (KP) dan faktor resiko (PR) pada TPA baru tidak menjadi pengaruh yang signifikan terhadap persepsi penerimaan (PP) TPA baru di masyarakat

\section{Kesimpulan}

Hasil dari analisis structural equation modelling (SEM) dilakukan untuk mengetahui model hubungan antar faktor, adapun hasil dari analisis SEM menununjukkan Hubungan dari struktur model diperoleh bahwa hubungan status sosial (SS) hanya bernilai signifikan terhadap variabel Persepsi Manfaat (PM), yang ditunjukkan dengan hasil t-value $(3,003) \geq 1,96$ dan $p$-value $(0,027) \leq 0,05$. Hal ini ini menunjukan bahwa semakin tinggi status sosial masyarakat akan meningkatkan persepsi manfaat terhadap TPA. Sedangkan persepsi penerimaan terhadap TPA secara signifikan dipengaruhi dari persepsi informasi (PI) dan persepsi manfaat (PM). Persepsi penerimaan terhadap TPA Baru secara signifikan dipengaruhi dari persepsi informasi (PI) dan persepsi manfaat (PM), hasil ini mengkonfirmasi bahwa untuk persepsi masyarakat pada sesuatu yang baru dalam hal ini TPA baru, yang mampu merefleksikan penerimaan masyarakat adalah faktor penerimaan informasi dan manfaat yang dirasakan. Untuk faktor Kepercayaan (KP) dan faktor resiko (PR) pada TPA baru tidak menjadi pengaruh yang signifikan terhadap persepsi penerimaan (PP) TPA Baru di masyarakat.

\section{Ucapan Terima Kasih}

Terimakasih kepada segenap pembimbing, pengelola, dan teman-teman MTL ITATS yang telah membantu support dan segala bentuk dukungan lain, semoga selalu menjadi kebaikan dimanapun berada 


\section{Referensi}

[1] D. Hoornweg and P. Bhada-Tata, "What a Waste 2012 Final," Urban Dev. Local Gov. Unit World Bank, p. 93, 2012.

[2] P. S. Alala and A. Budianto, "Evaluasi Kinerja Bank Sampah "Sekar Arum “di Perumahan,” J. Teknol. dan Manaj., vol. 1, no. 2, pp. 95-102, 2020.

[3] F. E. M. Ghazali, S. Syafalni, and S. M. Noor, "Public Perception on the Current Solid Waste Management System in Malaysia: A Comparative Study of Matang Landfill and Bukit Tagar Sanitary Landfill ( BTSL )," vol. 32, no. 5, pp. 872-883, 2014.

[4] Agus Budianto, Suhartini, and Suparjo, "Peningkatan Export Produk Berbahan Kertas Bekas Semen Di Surabaya Jawa Timur,” 2017, pp. E7-E12.

[5] A. Budianto, S. Suparjo, and S. Suhartini, "Pendampingan dan Peningkatan UKM Berbahan Kardus bernilai Unik di Surabaya Jawa Timur,” vol. 03, no. 01, pp. 68-72, 2018.

[6] A. Budianto, "Pirolisiss Botol Plastik Bekas Minuman Air Mnieral Jenis Pet Menjadi Fuel," Semin. Nas. Sains dan Teknol. Terap. V, pp. 201-206, 2017.

[7] A. Budianto, Romiarto, and Fitrianingtyas, "Pemanfaatan limbah kakao (Theobroma cacao 1) sebagai karbon aktif dengan aktifator termal dan kimia," in Research Gate, 2017, no. August, pp. 207-212.

[8] J. P. Radar Bojonegoro, "TPA Banjarsari Overload, Pemkab Bingung," no. April 2018, Bojonegoro, Apr-2018.

[9] E. Kusdarini, S. Suyadi, B. Yanuwiadi, and L. Hakim, "Analysis of Water Sources Availability and Water Quality in Dry and Rainy Season in Dry Land Areas, North Gresik, Indonesia," Pollut. Res., vol. 38, no. 4, pp. 58-65, 2019.

[10] E. Kusdarini, S. Suyadi, B. Yanuwiyadi, and L. Hakim, "The Supply of Clean Water and The Problems in Benjeng Sub-District, Gresik, Indonesia," in Proceedings of the 13th International Interdisciplinary Studies Seminar, 2019, pp. 1-7.

[11] M. Sánchez-Arias et al., "Socio-environmental assessment of a landfill using a mixed study design: A case study from México," Waste Manag., vol. 85, pp. 42-59, 2019.

[12] E. Kusdarini, S. Suyadi, B. Yanuwiyadi, and L. Hakim, "Model of People's Perception of Water Treatment Equipment: Preliminary Study of the Lake Water Treatment Plan in Gresik Dry Land Area, Indonesia," in Proceedings of the 13th International Interdisciplinary Studies Seminar, 2019, pp. 1-9.

[13] Z. E. Tamod, "Studi Mitigasi Sampah Kota Manado." Program Pascasarjana, Fakultas Pertanian, Universitas Brawijaya, Malang, p. 2008, 2008.

[14] BPS Bojonegoro, Kabupaten Bojonegoro Dalam Angka 2019. Bojonegoro: BPS Kabupaten Bojonegoro, 2019.

[15] R. V. Krejcie and D. W. Morgan, "DETERMINING SAMPLE SIZE FOR RESEARCH ACTIVITIES," Educ. Psychol. Meas., vol. 30, pp. 607-610, 1970.

[16] S. Tantitaechochart, N. Paoprasert, and K. Silva, "Analyzing local perceptions toward the new nuclear research reactor in Thailand," Nucl. Eng. Technol., 2020.

[17] A. Joshi, S. Kale, S. Chandel, and D. Pal, "Likert Scale: Explored and Explained," Br. J. Appl. Sci. Technol., vol. 7, pp. 396-403, Jan. 2015.

[18] E. Kusdarini, B. Yanuwiadi, L. Hakim, and S. Suyadi, "Adoption Model of Water Filter by The Society of Lake Water Users in Dry Land Area, Gresik, East Java, Indonesia," Int. J. Adv. Sci. Eng. Inf. Technol., vol. 10, no. 5, pp. 2089-2096, 2020. 
[19] I. G. G. Umbara, N. Luh, and P. Suciptawati, "MASYARAKAT MENGENAI TATO MENGGUNAKAN STRUCTURAL EQUATION MODELING ( SEM )," E-Jurnal Mat., vol. 7, no. November, pp. 364-370, 2018.

[20] J. F. Hair Jr, L. Hopkins, M. Georgia, and S. College, "Partial least squares structural equation modeling ( PLS-SEM ) An emerging tool in business research," Eur. Bus. Rev., vol. 26, pp. 106$121,2014$.

[21] S. Wijanto, Structural Equation Modeling dengan LISREL 8.8 Konsep dan Tutorial. Yogyakarta: Graha Ilmu, 2008.

[22] S. Tatsuki, H. Hayashi, D. B. Zoleta-nantes, and M. Banba, "The Impact of Risk Perception , Disaster Schema, Resources, Intention, Attitude , and Norms upon Risk Aversive Behavior among Marikina City Residents : Structural Equation Modeling with Latent Variables," pp. 110, 2002.

[23] H. M. Haught, "Perceived Risk and Expected Benefits Impact Social Class Differences in Health Risk Behavior." 2015.

[24] M. Siegrist and G. Cvetkovich, "Perception of Hazards: The Role of Social Trust and Knowledge,” Risk Anal., vol. 20, pp. 713-720, May 2002. 